DOI: https://doi.org/10.3126/jbssr.v5i2.35231

\title{
Factors Influencing Investment in Mutual Fund Schemes of Nepal
}

\author{
Dipesh Pote Shrestha ${ }^{1}$ \\ Yogesh Man Shrestha² \\ Lecturer
}

Tri Chandra Campus, Tribhuvan University, Nepal

Article History

Received 06 July 2020

Reviewed 17 July 2020

Revised 16 Sept 2020

Plagiarism Checked

17 Oct 2020

Revised 2 Nov 2020

Accepted 15 Nov 2020

Keywords

investment, mutual fund, Nepal stock exchange, scheme selection

Journal of Business

and Social Sciences

Research (ISSN: 2542-

2812). Vol V, No. 2, Dec

2020

\section{Abstract}

The history of mutual funds in Nepal began with the introduction of "NCM Mutual Fund 2050" in 1993. The Mutual Fund Regulation, 2010 has played an important role in development of Mutual funds as momentous progress can be observed after its implementation. The mutual fund sector has raised Rs. 17.49 billion through public offering and this figure is projected to reach Rs. 19.79 billion by the end of FY 2019/20. Considering the momentous growth in the mutual fund industry this study attempts to analyse the investment pattern of Nepalese mutual fund Investors based on various parameters. This study also attempts to identify the critical factors influencing investment in mutual fund schemes of Nepal. The results indicate that the investors are moderately averse to mutual fund schemes. The results further show that the investors chose mutual fund schemes, being relied on key performance indicators of Mutual funds and their perception towards several aspects of mutual fund schemes. Moreover, fund managers' qualities and corporate governance factors are considered important though the results are not statistically significant.

\section{Introduction and Study Objective}

Mutual fund is a trust that collects fund from a relatively large number of investors with a common financial goal. A mutual fund is an indirect form of investment in the financial market that offers advantages of diversification, professional

${ }^{1}$ Shrestha is an MBA graduate from the CG Institute of Management (affiliated to Limkokwing University of Creative Technology). He is employed at Nepal Reinsurance Co. Ltd. His email ID is dipeshshrestha908@gmail.com

${ }^{2}$ Shrestha is Assistant Professor at the Department of Statistics, Tri Chandra Campus, Tribhuvan University. 
management, low cost of investment, liquidity and tax benefit (Chawla, 2014). The Securities Act, 2007 outlines that a mutual fund is the fund created out of amount deposited by participants in a collective investment scheme in accordance with a contract that has been taken in its custody by a scheme manager with the objective to provide an efficient investment service.

\subsection{Background of Mutual Fund in Nepal}

NIDC Capital Market is the pioneer institution of mutual fund schemes in Nepal which issued "NCM Mutual Fund 2050" in 1993 and "NCM Mutual Fund-2059" in 1993/94. Similarly, the "Citizen Unit Scheme 2052" managed by Citizen Investment Trust was issued in 1994/95 as an open ended mutual fund which is operational till date. These three mutual funds operated in an environment that lacked adequate supervision and regulation.

The establishment of Securities Board of Nepal (SEBON) as the apex regulatory body for the securities markets in 1993 and the subsequent formulation and enactment of Securities Act, 2006, Mutual Fund Regulations Act, 2010 and Securities Businessperson (Merchant Banker) Regulations,2008. have enabled proper licensing, monitoring, supervision and regulation of mutual fund alongside investment banking activities In Nepal.

Currently, 9 merchant banking institutions are operational as mutual fund managers. They have issued a total of 22 mutual fund schemes since the enactment of the Mutual Fund Regulations, 2010 in Nepal. Out of 22 schemes, 17 close-ended and 1 open-ended mutual funds are operational while four have matured. All 9 merchant banking institutions are subsidiaries of Nepalese commercial banks and have received the patronage in the role of fund sponsor in the respective mutual fund schemes.

The gross funds raised from the operational mutual fund schemes were Rs.17.49 billion as of $19^{\text {th }}$ March, 2020 with the funds being invested in diverse sectors within Nepal. Three more mutual fund schemes are in the pipeline and worth Rs. 2.3 billion. Thus, the capital raised through mutual fund is projected to be Rs. 19.79 billion by the end of FY 2019/2020. The ratio of asset under management of mutual fund to GDP of Nepal stands at 0.50 per cent. In perspective, these ratios were 10.76 per cent for India and 118.91 per cent for the USA (World Bank, 2019). Thus, Nepal lags significantly behind in this sector and there is a potential for significant expansion and growth of mutual funds in Nepal.

\subsection{Statement of Problem}

Priority to invest in mutual fund remains comparatively less in comparison to other financial assets in Nepal. Fixed deposit remains the most common and preferred financial security among Nepalese investors (Dangol \& Shakya, 2017). Furthermore, investors preferred to invest in shares in comparison to mutual fund schemes even though mutual fund investment provide benefits such as 
reservations in public issue, avoidance of dual taxation in addition to the dividends provided to its investors.

In FY 2018/19, six mutual fund schemes were approved by SEBON for public issue. However, none of these six schemes got fully subscribed within the first four working days of the public offering and had to period of issue were closed on a later date mentioned in their prospectus. Out of the six schemes, NMB-50 was oversubscribed and NIBL Sahabhagita Fund (open-ended scheme) got fully subscribed. However, Nabil Balanced Fund 2, Siddhartha Growth Scheme 2, NIC Asia Balance Fund and Citizen Mutual Fund II were undersubscribed by $6.67 \%$, $14.29 \%, 39.6 \%$ and $44 \%$ respectively (Investment management service, 2020). The features of the undersubscribed mutual fund were similar to those already in existence while NMB-50 and NIBL Sahabhagita fund had unique features. Investors have become more careful about their investments and hence mutual fund managers need to design their mutual fund schemes as per the targeted nature of investors. Furthermore, a single type of mutual fund scheme cannot address the need of a wide range of investors and it is important to critically analyse the investors based on their characteristics, investment objectives and risk appetite and incorporate these factors while designing the mutual fund schemes.

Even though a fair amount of prior studies on factors influencing investment in mutual fund has conducted in neighbouring Asian countries and parallel inferences can be drawn. Due to brief operational history of mutual fund in Nepal, difference in the investment climate and differences in financial teachings, financial literacy, nature of mutual fund schemes, and upbringing might cause significant deviations from the assumed standard. The amendment of Mutual Fund Regulations, 2010 has enabled insurance companies and other financial institutions to operate mutual fund schemes. This new provision will facilitate the growth in number of mutual fund managers and make the mutual fund industry competitive. However, an eminent risk of failure to attract and satisfy investors to mutual fund schemes exists as the investors currently exhibit aversion to mutual fund. Fund managers need to design mutual fund schemes that are tailored for specific types of investors to attract investment. Thus, it is vital to study the factors influencing investment in mutual fund schemes of Nepal.

\subsection{Study Objectives}

The main objective of this study is to identify factors influencing investment decision in mutual funds by individual investors in Nepal. The two specific objectives of this study are as follows:

$>$ To analyse the demographic characteristics of individuals investing in mutual fund schemes of Nepal; and

$>$ To assess the perception level of individual investors towards mutual fund schemes of Nepal 


\section{Literature Review}

The primary objective of any investment is to earn a target rate of returns and thus performance indicators remain the most important information source for any investor. The primary objective of mutual fund investors was to obtain monetary benefit (D'Silva, D'Silva, \& Bhuptani, 2012). However, a study conducted in 1996 found that other parameters in addition to the performance of mutual fund were considered by investors in their selection process which included factors such as fund manager reputation, qualities of schemes and management fees (Capon, Fitzsimons, \& Alan Prince, 1996).

\subsection{Perception towards Mutual Funds}

An individual is susceptible to prejudice based on their past experience and perception towards any event or object. An investor is not free from such prejudice and perception. A tendency of investors to invest based on perceived performance rather than actual performance is a suitable example. A study in 2018 showed that investors made investment decisions based on their preconceptions and perception towards the Mutual Fund sector without conducting proper analysis (Singal \& Manrai, 2018). Similarly, certain investors were found to perceive mutual fund as an ancillary investment avenue and refrained from investing in them unless they had surplus funds (Alamelu \& Indhumathi, 2017). Furthermore, a distinction between perceived and actual performance exists as Investors may make investment decisions based on their performance rather than performance. The perception of the investor is a driving factor influencing investment in mutual fund schemes and hence this forms the basis for the first hypothesis.

$\mathrm{H}_{1}$ : The Perception towards Mutual Fund and Investment in Mutual fund has a positive significant relationship.

\subsection{Ease of Investment}

Liquidity is a prerequisite for any financial investment and investor may not prefer to invest in illiquid financial security. Liquidity in the mutual fund was considered to be an important factor by investors (Mali, 2018) as a lack of liquidity would make any investment unattractive. Close-ended schemes are traded in the secondary market and require a market maker or buyer/seller on the other side for completion of the transaction while open-ended scheme can be directly bought or sold through the fund managers. Hence, open-ended schemes were considered to be more attractive in comparison to close-ended mutual fund schemes in terms of liquidity (Alamelu \& Indhumathi, 2017). Nevertheless, entry and exit fees are charged by the fund manager in case of open-ended schemes. The fees charged by the fund manager have a direct impact on the profitability of the investment and thus the fees were considered to be an important factor for open-ended mutual fund schemes (Dhar, Salema, \& Saha, 2017). The availability of selected mutual fund scheme with ease and low entry and exit barriers are vital 
in promoting and attracting investors. Hence, the liquidity of mutual fund is an important factor taken into consideration by the investor and this gives rise to the second hypothesis.

$\mathrm{H}_{2}$ : Ease of Investment has a positive impact on Investment in Mutual Fund Schemes.

\subsection{Performance of Mutual Fund}

It is highly imperative to draw a distinction between the actual and perceived performance of mutual fund. In the context of Nepal, the actual monthly return of mutual fund was relatively lower than the returns of NEPSE (Rauniyar, 2016; Bajracharya, 2017). Furthermore, only 60 per cent of the mutual fund distributed cash dividends regularly and dividends ranged from 10 per cent to 60 per cent (Rakhal, 2018). Fund managers' experience had a significant impact on the performance of the mutual fund as older mutual fund schemes performed better in comparison to new schemes (Upadhyaya \& Chhetri, 2019). Hence, only selective mutual fund schemes were found to have provided optimal result to the investors.

Even though Mutual Fund schemes are not able to constantly provide returns higher than the market, perception regarding their performance varies from the fact. Investors expected higher returns with lower investment risks from fund managers even though such expectations are in contradiction with the widely accepted concept of risk-return trade-off (Chawla, 2014). Only selective mutual funds have been able to outperform the market and it is unrealistic to expect mutual funds to generate higher returns while reducing risk simultaneously. Such expectations by individual investors indicates the desire to obtain additional returns or benefits for parting with their funds and allowing the fund manager to manage their investments. In addition to dividends, other monetary benefits such as tax savings and benefits was an important aspect for Mutual Fund Investors (Ul-Hameed, Imran, Maqbool, Ahmed, \& Azeem, 2019). In addition to returns generated by the investors the risk reduction through diversification was considered important by investors (Shafee, 2018). The actual and perceived performance of mutual fund are important factors that influence investment in mutual funds and various factors such as the investor's expectation might influence the perception towards the performance of mutual fund schemes. This forms the basis for the third hypothesis:

$\mathrm{H}_{3}$ : Performance of Mutual Fund has a significant positive impact on investment in mutual fund.

\subsection{Corporate Governance and Transparency}

An agency problem exists between the fund manager and investor. The objectives of the investor and fund manager are inherently different thus investors seek professionalism and good corporate governance in the fund 
managers. High level of professionalism and good corporate governance act as a supporting factor and assure the investors that their financial interests are kept ahead of the interest of the fund manager. A study found that businesspersons and salaried individuals had high concerns regarding the credibility of fund manager as it has a direct implication in the safety and performance of their investments (Chawla, 2014). Furthermore, investors had the tendency to contemplate their past experiences with investment in financial securities while making their investment decisions (Arathy, Aswathy, Pravitha, \& Sai, 2015; Singal \& Manrai, 2018). Thus, it is paramount that investors maintain a high level of professionalism and act in the best interest of investors. The investors need to exhibit a strong ethical base while conducting the investment activities. Moreover, Investors prioritized transparency in the accounting and considered record keeping process to be important factor in their investment decision (Rehan, Naz, \& Umer, 2018; Singal \& Manrai, 2018; Ul-Hameed, Imran, Maqbool, Ahmed, \& Azeem, 2019). Professional management in mutual fund is another factor that influences investors to invest through mutual funds (Unnamali, 2016). Hence, the investment decisions of the fund manager need to be logical and investments made only after adequate research and study. A lack of corporate governance and transparency in the investment process can act as a deterrence for the investors and may induce lower investment. Thus, Corporate Governance factor is a necessary prerequisite for investment while this factor may have a significantly less role in attracting investment in Mutual Fund and hence the following fourth hypothesis was formulated.

$\mathrm{H}_{4}$ : Corporate Governance and Transparency in Mutual Fund has a positive significant relationship with investment in mutual fund.

\subsection{Fund Managers' Qualities}

Fund managers are responsible for the performance and activities carried out by the investor. The qualities, expertise, credit rating, and image of a fund manager have a considerable impact on the selection of the fund. Individual investors had a tendency to seek expert advice and used credit ratings as a reliable basis for selection of the fund schemes (Arathy, Aswathy, Pravitha , \& Sai, 2015). Similarly, the image of fund sponsor and the association of the fund manager were considered by the investors during their investment process. Furthermore, schemes associated and promoted by reputed financial institutions were preferred by investors in comparison to other mutual funds (Nihar \& Bhamidipati, 2012). On the contrary, another study conducted in Nepal found that investors did not have preference for any specific fund manager (Bajracharya \& Mathema, 2017). In addition to the professional services provided by a mutual fund factors such as cost efficiency, experience of fund manager, safety of funds was amongst the features of fund managers that Investors considered while investing in mutual fund. The selection of mutual fund therefore depends on various aspects of the fund managers which could be further explored. Factors such as the external 
credit rating, reputation of the fund manager, experience in managing mutual funds and historic performance of the fund manager are factors that could influence the investment decision of the investor. This forms the basis for the fifth hypothesis.

$\mathrm{H}_{5}$ : The qualities of the Fund Manager and Investment in Mutual Fund have a significant positive relationship.

Initially, return and performance of mutual fund were considered as the only two factor influencing investment. However, extensive studies conducted have provided strong evidence that even other factors play a substantial role in the mutual fund decision-making process. More recent studies have indicated that factors such as demographics, perception of an investor, nature of the fund, liquidity, transparency and corporate governance in management of the fund, fund manager qualities and ratings assigned by external rating agencies amongst many other factors influence the final selection of a mutual fund.

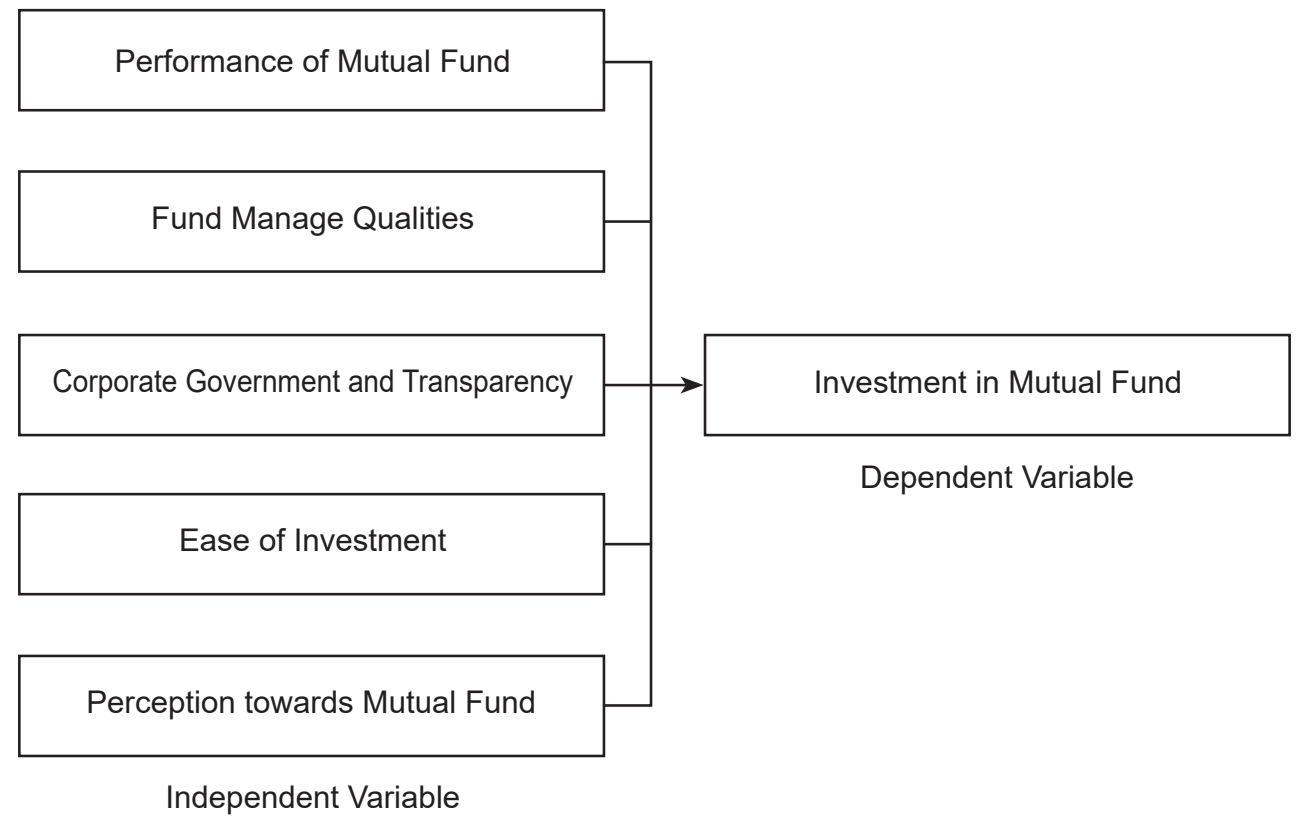

Figure 1: Conceptual Framework of the Study

\section{Research Methods}

The study shall use descriptive and explanatory research design shall be used. The descriptive research design shall be used to describe the characteristics of the mutual fund investor and their perception towards mutual fund. Similarly, the explanatory research design will be used to explain the relationship between the performance, perception, fund managers' qualities, and ease of investment, corporate governance factors and investment in mutual fund schemes. 
The review of literature indicates that various factors such perception towards mutual fund, liquidity, profitability, past experience, diversification of portfolio, dividend history of mutual fund, credit rating of fund manager, disclosure and transparency practices, and qualities of fund manager among other have a positive impact on the selection and investment in mutual fund schemes. These factors were further reviewed and grouped into five distinct factors i.e. perception towards mutual fund, performance of mutual fund, ease of investment factor, corporate governance and transparency factor and Fund Managers' Qualities factor.

The perception of the investors has a significant influence in the selection of the mutual fund schemes and thus the perception factor was considered as the first independent variable for the study. Similarly, liquidity is a prerequisite for any investment and low initial investment enables investor to test the investment opportunity prior to significant financial commitments which have been grouped under the ease of investment factor.

The primary objective of any financial transaction is to earn a suitable return at the desired risk level. Dividend history, risk diversification and returns from mutual funds are the key components under the performance of mutual fund factor. Mutual fund schemes are regulated and should aim to attain the ideal status as forecasted in prospectus of the company. Furthermore, conflict of interest may exist between investors and fund managers hence good governance and transparency in transactions in essential for mutual fund schemes and hence corporate governance and transparency was considered the fourth factor influencing investment in mutual fund schemes. Professional management is one of the primary reasons for selection of the mutual fund. Investors view the external credit rating and image of the fund manager/fund sponsor while investing in mutual funds and these components have been represented by the Fund managers' qualities factors.

The estimation of the population size of mutual fund investors was not accurately available and thus Cochran (1977) sample size formula was found as the most appropriate tool for determining the sample size. The adequate sample size was found to be $237^{3}$ and the data shall be collected using convenience sampling techniques.

The multiple regression model of the study are as follows:

$Y=\beta_{0}+\beta_{1} X_{1}+\beta_{2} X_{2}+\beta_{3} X_{3}+\beta_{4} X_{4}+\beta_{5} X_{5}+u$

Where,

$\mathrm{X}^{1}=$ perception towards mutual fund

$\mathrm{X}_{2}=$ ease of investment

${ }^{3} Z$ value $=1.96$ (95\% confidence Level), $e=6.3 \%$ and $p=50 \%$ (at maximum variance Level) used to calculate the sample size. 
$\mathrm{X}_{3}=$ performance of mutual fund

$\mathrm{X}_{4}=$ corporate governance \& transparency

$\mathrm{X}_{5}=$ fund managers' qualities

$Y=$ investment in mutual fund

$\beta_{0}=$ Constant Term

$\beta_{1 .} \beta_{5}=$ Coefficients

$\mathrm{u}=$ Error term

\subsection{Instrumentation}

In order to achieve the objective of the study a well-structured questionnaire was developed and used to collect primary data from Individual Mutual Fund investors. The respondents responded in the form of multiple-choice options and 5-point Likert Scale. The questionnaire was finalized after conducting a pilot survey among 30 individual investors. Based on the pilot study, the questionnaire was refined with a view of ensuring that responses from respondents could be obtained with accuracy.

\subsection{Methods of Analysis}

The data derived from the questionnaire were rearranged where necessary to facilitate this study. Mean, median, standard deviation, skewness, kurtosis, correlation, and regression to describe and analyse the relationship between dependent and independent variables. The Cronbach's Alpha was computed to ensure consistency and reliability of data.

\subsection{Assumptions}

$>$ Mutual Fund Investors make rational investment decisions

$>$ The responses provided by the Mutual Fund Investors are factual and based on their innate belief and perception towards Mutual Fund schemes.

$>$ Mutual Fund Investors are open to investing in Multiple Mutual Fund Schemes.

\subsection{Limitations of the Study}

$>$ Convenience sampling technique, a non-probability sampling method, was used to collect data, as identification of Mutual Fund Investors was difficult.

$>$ The study has not been conducted over an extended period and hence the study might face biases based on the current market conditions and recent events.

> The study is primarily concentrated within the Kathmandu valley due to centralisation of merchant banking services. 


\section{Data Analysis and Discussions}

\subsection{Respondent Profile}

The study has used five independent variables and one dependent variable to identify and analyse the factors influencing investment in mutual fund schemes. The five independent variables were further represented by twenty-one items relating to these factors. The study collected 237 responses from mutual fund investors and the respondent's profile has been presented in Table 1. The male respondents (69.6 per cent) are higher than female respondents (30.4 per cent) indicating that male were more active in investment and financial activities. Married individuals (55.3 per cent) were more active compared to single individuals ( 44.7 per cent). The respondents consisted of younger individuals with individuals between 20 years and 30 years representing 49.8 per cent of the sample size. Respondents having graduates or post-graduate degrees and individuals with professional courses represented 90.3 per cent. The highest level of participation was from employees working at private entities (60.8 per cent) followed by business owners (18.1 per cent) indicating that the risk and uncertainty associated with these professions may have caused these individuals to seek alternative avenues for income.

Table 1

Respondents Profile

\begin{tabular}{llll}
\hline Variable & Classification of Variables & Frequency (N) & Percentage (\%) \\
\hline \multirow{2}{*}{ Gender } & Male & 165 & 69.6 \\
& Female & 72 & 30.4 \\
Marital Status & Married & 131 & 55.3 \\
& Single & 106 & 44.7 \\
Age Groups & $20-30$ & 118 & 49.8 \\
& $30-40$ & 56 & 23.7 \\
& $40-50$ & 34 & 14.4 \\
& $50-60$ & 19 & 8.1 \\
Educational Qualification & 10 & 4.3 \\
& 60 and Above & 4 & 1.7 \\
& High School Level & 19 & 8 \\
& Diploma & 96 & 40.5 \\
& Graduate & 86 & 36.3 \\
Occupation & Post Graduate & 32 & 13.5 \\
& Professional Courses & 33 & 13.9 \\
& Government Employee & 144 & 60.8 \\
& Private Employee & 43 & 18.1 \\
Income Groups (Rs) & Business Owners & 11 & 4.6 \\
(per month) & Retired & 6 & 2.5 \\
& Student & 15 & 6.3 \\
& Below 15,000 & 48 & 20.3 \\
& 15,000 - 30,000 & 65 & 27.4 \\
& $30,000-50,000$ & 56 & 23.6 \\
\hline
\end{tabular}

Note. Based on the researcher's survey, 2019 
The respondents belonging to income category of below $15,000,15,000-30,000$, $30,000-50,000,50,000$ to 100,000 and 100,000 and above is 6.3 per cent, 20.3 per cent, 27.4 per cent, 23.6 per cent and 22.4 per cent respectively. Indicating that individuals from lower income category did not participate in mutual fund schemes even though it required lower investment compared to other investment avenue.

Table 2

Size of Investment in Mutual Fund Schemes

\begin{tabular}{llll}
\hline $\begin{array}{l}\text { Investment in Mutual Fund } \\
\text { (Percentage of Portfolio) }\end{array}$ & Frequency (N) & Percentage (\%) & $\begin{array}{l}\text { Cumulative } \\
\text { Percentage (\%) }\end{array}$ \\
\hline Below 10\% & 72 & 30.4 & 30.4 \\
$10 \%$ to 25\% & 64 & 27.0 & 57.4 \\
$25-50 \%$ & 69 & 29.1 & 86.5 \\
$50-75 \%$ & 32 & 13.5 & 100.0 \\
Total & 237 & 100.0 & \\
\hline
\end{tabular}

Note. Based on the researcher's survey, 2019

The percentage of mutual fund investment with respect to the investor's portfolio was categorized into 5 groups as presented in Table 2. The proportion of respondents investing in mutual fund schemes below 10 per cent, 10 per cent to 25 per cent, 25 per cent to 50 per cent and 50 per cent to 75 per cent is 30.4 per cent, 27 per cent, 29.01 per cent and 13.5 per cent while none of the respondents had invested higher than 75 per cent of their portfolio in mutual funds. Furthermore, 85.6 per cent of the respondents had invested 50 per cent or lower in mutual fund when compared to their investment portfolio which indicates that mutual fund did not comprise a significant proportion of the investor's portfolio and was not assigned the highest priority.

Table 3 presents the overall score of the five independent variables derived from their respective items. Similarly, the variance and standard deviation were the least among fund managers' qualities and corporate governance \& transparency in comparison to the other factors. The ease of investment, performance of mutual fund and corporate governance and transparency factors were slightly asymmetric as the values lies between $-1 / 2$ and 0 . Similarly, the perception towards mutual fund and fund managers' qualities factor were moderately left skewed as the values lies between -1 and $-1 / 2$. As all the factors are negatively skewed the data it indicates that majority of the respondents in the range of 4 to 5 as presented in Table 3 . The kurtosis of all the 5 factors is within the range of -3 to 3 range which is satisfactory. The ease of investment and performance of mutual fund factors were slightly platykurtic and the perception towards mutual fund, fund manager's' qualities and corporate governance \& transparency factors were leptokurtic. However, the value of perception towards mutual fund for skewness and kurtosis indicate asymmetric and highly leptokurtic distribution. 
Table 3

Descriptive Statistics of Independent Variables

\begin{tabular}{|c|c|c|c|c|c|c|}
\hline Factors & Mean & Median & Variance & St. D & Skewness & $\begin{array}{l}\text { Excess } \\
\text { Kurtosis }\end{array}$ \\
\hline Perception towards Mutual Fund & 3.46 & 3.5 & 0.396 & 0.63 & $(0.9630)$ & 2.537 \\
\hline Ease of Investment & 4.06 & 4.00 & 0.461 & 0.68 & $(0.3850)$ & $(0.377)$ \\
\hline Performance of Mutual Fund & 3.87 & 4.00 & 0.638 & 0.80 & $(0.3900)$ & $(0.435)$ \\
\hline $\begin{array}{l}\text { Corporate Governance \& } \\
\text { Transparency }\end{array}$ & 4.17 & 4.00 & 0.322 & 0.57 & $(0.4980)$ & 1.066 \\
\hline Fund Managers' Qualities & 4.20 & 4.33 & 0.344 & 0.59 & $(0.6480)$ & 0.675 \\
\hline
\end{tabular}

Note. Calculations based on the researcher's survey, 2019

\section{2 Reliability Test}

A high value of Cronbach's alpha indicates good internal consistency of the items in the scale. Table 4 presents the Cronbach's alphas for the entire questionnaire (55 items) and the five independent variables (21 items) which were 0.776 and 0.842 respectively and these values are above the acceptable limit of 0.7 . Hence, the data has good internal consistency and reliability.

Table 4

Reliability Statistics

\begin{tabular}{lll}
\hline Variables & Number of Items & Cronbach's Alpha \\
\hline Perception towards Mutual Fund & 10 & 0.876 \\
Ease of Investment & 2 & 0.815 \\
Performance of Mutual Fund & 3 & 0.901 \\
Corporate Governance and Transparency & 3 & 0.85 \\
Fund Manager's Qualities & 3 & 0.806 \\
\hline
\end{tabular}

Note. Calculations based on the researcher's survey, 2019

\subsection{Inferential Analysis}

The perception towards mutual fund was positively and significantly correlated (at 0.05 level) to ease of investment in mutual fund, performance of mutual fund and corporate governance factors. The ease of investment factors was significantly and positively correlated with all 4 other factors. Performance of mutual fund had a significant and positive relationship with all 5 factors. Corporate governance factor had a significant and positive correlation with all the other 5 factors.

Similarly, corporate governance and ease of Investment were strongly correlated and were significant at 0.05 and 0.01 levels. The factors influencing investment in mutual fund had a significant correlation with one another. In such an instance, the corporate governance and ease of investment were found to have strong and significant correlation, which could infer that corporate governance factor 
could still be a factor that fit in the multiple regression model due to its correlation with ease of investment factor which is significant at both 0.05 and 0.01 level of significance as shown on Table 5.

In terms of Investment in mutual fund perception towards mutual fund, ease of investment and performance of mutual fund were significant at 0.01 levels with positive Pearson coefficients hence the 3 null hypotheses were rejected and $\mathrm{H} 1$, $\mathrm{H} 2$ and $\mathrm{H} 3$ were accepted. Similarly, corporate governance \& transparency and fund managers' qualities were not found to be significant thus $\mathrm{H} 04$ and $\mathrm{H} 05$ were accepted. Low Pearson Correlation Coefficient for Performance factor indicates gave lower weight to actual performance of the investor.

Table 5

Correlation of Factors influencing Investment in Mutual Fund Schemes

\begin{tabular}{|c|c|c|c|c|c|c|}
\hline & $X_{1}$ & $X_{2}$ & $X_{3}$ & $X_{4}$ & $X_{5}$ & Y \\
\hline \multirow[t]{2}{*}{$\overline{X_{1}}$} & & $.135^{\star}$ & $.144^{*}$ & $.159^{*}$ & 0.038 & $.346^{* *}$ \\
\hline & & 0.037 & 0.026 & 0.014 & 0.560 & 0.000 \\
\hline \multirow[t]{2}{*}{$X_{2}$} & & 1 & $.245^{\star *}$ & $.304^{* *}$ & $.134^{*}$ & $.335^{\star *}$ \\
\hline & & & 0.000 & 0.000 & 0.039 & 0.000 \\
\hline \multirow[t]{2}{*}{$X_{3}$} & & & 1 & $.169^{\star *}$ & $.140^{*}$ & $.287^{\star *}$ \\
\hline & & & & 0.009 & 0.031 & 0.000 \\
\hline \multirow[t]{2}{*}{$X_{4}$} & & & & 1 & $.459^{* *}$ & 0.101 \\
\hline & & & & & 0.000 & 0.121 \\
\hline \multirow[t]{2}{*}{$X_{5}$} & & & & & 1 & 0.032 \\
\hline & & & & & & 0.629 \\
\hline Y & & & & & & 1 \\
\hline
\end{tabular}

*. Correlation is significant at the 0.05 level (2-tailed).

**. Correlation is significant at the 0.01 level (2-tailed).

Note. Calculations based on the researcher's survey, 2019

Where,

$\mathrm{X}_{1}=$ perception towards mutual fund

$\mathrm{X}_{2}=$ ease of investment

$\mathrm{X}_{3}=$ performance of mutual fund

$\mathrm{X}_{4}=$ corporate governance \& transparency

$X_{5}=$ fund managers' qualities

$Y=$ investment in mutual fund

\subsection{Regression Analysis}

Initially, a multiple regression model was run considering all 5 independent variables as correlation is not a prerequisite for running a regression. The fund managers' quality factor and corporate governance \& transparency factor were 
found to be insignificant at 0.05 levels in the initial multiple regression model. These 2 factors were removed from the regression model forming a regression model with 3 independent variables.

Table 6

Regression Analysis

\begin{tabular}{lllll}
\hline Model & B & T-Value & P-Value & VIF \\
\hline (Constant) & -1.291 & -3.802 & 0.000 & \\
Perception towards Mutual Fund & 0.326 & 4.898 & 0.000 & 1.033 \\
Ease of Investment in Mutual Fund & 0.267 & 4.241 & 0.000 & 1.076 \\
Performance of Mutual Fund & 0.166 & 3.087 & 0.002 & 1.078 \\
R-Squared & 0.236 & & & \\
Adjusted R-Square & 0.226 & & & \\
Durbin-Watson Statistics & 1.973 & & & \\
F & 23.946 & & & \\
P- Value & 0.000 & & & \\
\hline
\end{tabular}

Note. Calculations based on the researcher's survey, 2019

The above regression table 4 summarizes the model performance with relevant analysis. As the R-value was 0.485 , investment decision had an overall positive relationship with perception towards mutual fund, performance of mutual fund and ease of investment in mutual fund. The $R$ square value was 0.236 and the adjusted $R$ squared was 0.226 which indicates that 22.6 per cent of the variation in placement percentage was explained by the 3 factors. Durbin-Watson value is 1.973. The independence of residual assumption is not violated because the Durbin-Watson value is very close to 2 . Therefore, the outliers have no influence on the regression model. In terms of multicollinearity, the tolerance value of all the variable is greater than 0.1 and all variance inflation factor (VIF) factors are less than 10 which indicates low correlation exists among the variables.

The coefficient of the constant is negative that indicates aversion from investment in Mutual Fund in general. The model coefficients were used to construct the regression equation as follows.

$\mathrm{Y}=-1.291+0.326 \mathrm{X}_{1}+0.267 \mathrm{X}_{2}+0.166 \mathrm{X}_{3}$

Where,

$\mathrm{X}_{1}=$ perception towards mutual fund

$\mathrm{X}_{2}=$ ease of investment in mutual fund

$\mathrm{X}_{3}=$ performance of mutual fund

And the value range for the independent variables range from (1 to 5,1 for Extremely Poor/Not at all Important and 5 Indicating Excellent/ Highly Important) 


\section{Conclusions and Implications}

The primary objective of this study was to identify the factors influencing investment in mutual funds. Based on the literature review, five factors were identified which could have significant influence on the investment decision of investors. Thus, response of 237 respondents were collected using questionnaire and 21 items related to the 5 factors were used to measure the response of the investor. The responses indicates that all the five factors were considered to be important and these factors were taken into account while making their investment decisions. The correlation of these five factors with respect to the investment in mutual fund was carried out. The Pearson Correlation Coefficient for all the factors remained less than 0.5 indicating a moderately low association of these factors with investment in mutual fund. Perception, ease of investment and performance factors were found to be statistically and positively correlated with investment in mutual fund.

Furthermore, Investors were found to the reliant on their perception (Singal \& Manrai, 2018) to make investment decisions regarding mutual funds. The primary objective of any investment is to generate return however the performance of mutual fund had the lowest weight among the 3 factors indicating monetary benefits was not the most important factor for the investors which was contradictory to the findings of (Nihar \& Bhamidipati, 2012). Moreover, Liquidity (Mali, 2018) was an important factor influencing the mutual fund investment and a lack of it would discourage investment .This study supports the findings of (Capon, Fitzsimons, \& Alan Prince, 1996) which had found that non-monetary benefits also influenced investment in mutual funds.

Corporate governance and fund manager's qualities did not have a significant correlation with investment in mutual fund. Nevertheless, the scores for these factors were high indicating that strong corporate governance and ease of investment remained a prerequisite for mutual fund investors. Compliance of the mutual fund scheme to the regulatory requirements and disclosure of all material information remained a key concern for the investors (Rehan, Naz, \& Umer, 2018; Singal \& Manrai, 2018; Ul-Hameed, Imran, Maqbool, Ahmed, \& Azeem, 2019). Similarly, professional management and image of the fund manager remained a high priority for the investors (Arathy, Aswathy, Pravitha, \& Sai, 2015). Furthermore, the negative coefficient of constant along with lower composition of mutual fund in investor's portfolio indicates that investors had moderate aversion from mutual fund schemes and hence it was considered an ancillary investment avenue by the investors similar to the findings of (Alamelu \& Indhumathi, 2017).

The findings of this paper have various implication for investors, mutual fund managers and policy makers in the Nepalese capital market. Firstly, this paper will help investors understand and improve their mutual fund selection process. Secondly, this paper has ample practical implications for mutual fund managers 
of Nepal in designing, targeting investors and marketing mutual fund schemes. The perception towards mutual fund, ease of investment and performance of mutual fund have significant influence in investment in mutual fund hence the fund managers need to consider these factors while designing the mutual fund schemes while ensuring that the financial goal of the target group of investors are properly addressed. Similarly, corporate governance and image of the fund manager were essential prerequisites for the investment hence it is importance for the fund manager to demonstrate professionalism and maintain good governance. Since mutual fund investors do not have any significant role and decision-making authority even though they are owners of the funds. The policy makers and regulators need to have a significant role in protecting financial interest of unit holder. This paper helps policy makers and regulators understand the factors considered important by the investors and instil mechanisms and policies to protect the interest of the unit holders. This would enable the promotion and improve the participation of the general investors in mutual fund and the capital market of Nepal.

\section{References}

Alamelu, K., \& Indhumathi, G. (2017). Investors perception towards mutual funds in Madurai District, Tamil Nadu. International Journal of Engineering Development and Research, 5(3), 1171-1175. Retrieved from https://www.ijedr.org/papers/ IJEDR1703166.pdf

Arathy, B., Aswathy, N., Pravitha, \& Sai (2015). A study on factors affecting investment on mutual funds and its preference of retail investors. International Journal of Scientific and Research Publications, 5(8). Retrieved from http://www.ijsrp.org/ research-paper-0815/ijsrp-p4473.pdf

Bajracharya, R. (2017). Mutual fund performance in Nepalese mutual fund units: An analysis of monthly returns. Journal of Advanced Academic Research, 3(2), 92100. Retrieved from https://doi.org/10.3126/jaar.v3i2.16758

Bajracharya, R., \& Mathema, S. (2017). A study of investors' preference towards mutual funds in Kathmandu Metropolitan City, Nepal. Journal of Advanced Academic Research, 4(2), 130-138. Retrieved from https://doi.org/10.3126/jaar.v4i2.19543

Capon, N., Fitzsimons, G. J., \& Alan Prince, R. (1996). An individual level analysis of the mutual fund investment decision. Journal of Financial Services Research, 10(1), 59-82. Retrieved from https://faculty.fuqua.duke.edu/ gavan/bio/GJF_ articles/mutual_funds_jfsr_96.pdf

Chawla, D. (2014). Empirical analysis of factors influencing investment in mutual funds in India. Global Business Review, 15(3), 493-503. Retrieved from https://www. researchgate.net/publication/274990926_An_Empirical_Analysis_of_Factors_ Influencing_Investment_in_Mutual_Funds_in_India

Cochran, W.G. (1977). Sampling techniques (3rd ed.). New Delhi: Wiley Eastern. Dangol, J., \& Shakya, R. (2017). Investment pattern of financially literate persons in Nepal. International Research Journal of Management Science, 2(1), 34-51. Retrieved from https://doi.org/10.3126/irjms.v2i0.28045 
Factors Influencing Investment in Mutual Fund Schemes of Nepal : Shrestha, Shrestha

Dhar, S., Salema, S., \& Saha, A. (2017). Factors affecting individual investor behaviour: Empirical evidence from mutual fund investors in Dhaka City. Management Development, 31(3\&4), 79-101. Retrieved from https://www.researchgate.net/ publication/329590486_FACTORS_AFFECTING_INDIVIDUAL_INVESTOR BEHAVIOR_EMPIRICAL_EVIDENCE_FROM_MUTTUAL_FUND_INVESTOR̄S_IN_ DHAKA_CITY

D'Silva, B., D'Silva, S., \& Bhuptani, R. (2012). A study of factors influencing mutual fund investment in India. The International Journal's Research Journal of Commerce \& Behaviour Sciences, 1(5), 23-30. Retrieved from http://www. theinternationaljournal.org/ojs/index.php?journal=rjcbs\&op=download\&page=articl e\&path $\% 5 \mathrm{~B} \% 5 \mathrm{D}=729 \&$ path $\% 5 \mathrm{~B} \% 5 \mathrm{D}=295$

Mali, N. (2018). Factors influencing mutual fund investors and risk averse behaviour in Western Maharashtra. ELK Asia Pacific Journal of Marketing \& Retail Management, 9(3), 1-19. Retrieved from https://www.researchgate.net/ publication/326265433_ELK_ASIA_PACIFIC_JOURNAL_OF_MARKETING_ RETAIL_MANAGEMENT_FACTORS_INFLUENCING_MUTUAL_FUND_ INVESTORS_AND_RISK_AVERSE_BEHAVIOUR_IN_WESTERN_ MAHARASHTRA

Nihar, L., \& Bhamidipati, P. N. (2012). Investors preferences for mutual fund investments-factor analysis. Drishtikon: A Management Journal, 3(1), 109-127. Retrieved from http://www.publishingindia.com/drishtikon/8/investors-preferencesfor-mutual-fund-investments-factor-analysis/127/993/

Rakhal, D. (2018). Current status of mutual fund schemes in Nepal. Journal of Nepalese Business Studies, 10(1), 85-95. Retrieved from https://www.nepjol.info/ index.php/JNBS/article/view/19136

Rauniyar, A. (2016). Performance evaluation of Nepalese mutual fund (Unpublished MPhil's research paper). Kathmandu University School of Management, Kathmandu University.

Rehan, R., Naz, S., \& Umer, I. (2018). Awareness and perception of investors towards mutual funds industry. RADS Journal of Social Sciences \& Business Management, 5(1), 1-14. Retrieved from https://jssbm.juw.edu.pk/index.php/jssbm/article/ view/51/43

Shafee, N. B. (2018). Mutual fund investment decision by Malaysian investor. International Journal of Academic Research in Business and Social Sciences, 8(11), 607-615. Retrieved from https://hrmars.com/papers_submitted/4934/Mutual Fund_Investment_Decision_by_Malaysian_Investor.pdf

Singal, V. S., \& Manrai, R. (2018). Factors affecting investment in mutual funds. Journal of General Management Research, 5(2), 96-107. Retrieved from https://www. myplexus.com/admin/admin1/assets/pdf_file/010_Varun_Singal.pdf

Ul-Hameed, W., Ismran, M., Maqbool, N., Ahmed, S., \& Azeem, M. (2019). A prospective study of factors that lead to invest in mutual fund: A mediating role of investor's perception. Accounting, 5(2), 69-80. Retrieved from https://www. researchgate.net/publication/330044693_A_prospective_study_of_factors_that lead_to_invest_in_mutual_funds_A_mediating_role_of_investor's_perception 
Upadhyaya, T. P., \& Chhetri, S. (2019). Performance base empirical analysis of mutual fund of Nepal. Journal of Financial Risk Management, 8(2), 43-54. Retrieved from https://www.researchgate.net/publication/333567337_Performance_Base_ Empirical_Analysis_of_Mutual_Fund_of_Nepal

World Bank, Global Financial Development. (2019). Mutual fund assets to GDP (\%). Retrieved from http://databank.worldbank.org/data/reports. aspx?source=1250 \&amp;series=GFDD.DI.07

\section{Acknowledgements}

The authors acknowledge the suggestions of Dr. Pramod Parajuli, CG Institute of Management.

\section{Funding}

The authors have received no funding or financial support from any individual or institution for carrying out the research.

\section{Conflict of interest}

The authors declare there is no conflict of interest in the research work. Neither the authors nor their respective employers have any substantial financial interest in any mutual fund schemes that have existed or are currently operational in Nepal. 


\section{Appendix}

Table A

Investment Objectives of Respondents

\begin{tabular}{lll}
\hline Investment Objective & Mean & Rank \\
\hline Capital Preservation & 4.09 & 2 \\
Recurring Cash In-Flow & 4.00 & 3 \\
Meeting Contingencies & 3.69 & 6 \\
Wealth Creation & 4.21 & 1 \\
Provision for Retirement & 3.90 & 4 \\
Tax Planning and Savings & 3.63 & 7 \\
Purchase of Assets & 3.84 & 5 \\
\hline
\end{tabular}

Table B

Preferred Investment Avenue of Respondents

\begin{tabular}{|c|c|c|c|c|}
\hline \multirow{2}{*}{ Investment Avenue } & \multicolumn{2}{|c|}{ Male } & \multicolumn{2}{|c|}{ Female } \\
\hline & Mean & Rank & Mean & Rank \\
\hline Government Securities & 2.8 & 6 & 3.49 & 4 \\
\hline Bank Deposit & 3.75 & 3 & 4.25 & 1 \\
\hline Debenture & 2.98 & 5 & 3.24 & 6 \\
\hline Insurance Policy & 3.35 & 4 & 3.43 & 5 \\
\hline Mutual Fund & 3.82 & 2 & 3.92 & 3 \\
\hline Shares & 4.24 & 1 & 4.17 & 2 \\
\hline
\end{tabular}

Table C

Ratings of Respondents for Independent Variables

\begin{tabular}{lllll}
\hline Independent Variables & Range & Mean & $\begin{array}{l}\text { Standard } \\
\text { Deviation }\end{array}$ \\
\cline { 2 - 5 } & Returns of Mutual Fund & $1-5$ & 3.46 & 0.87 \\
& Risk Management by Mutual Fund & $1-5$ & 3.56 & 0.94 \\
& Selection of Financial Securities & $1-5$ & 3.42 & 0.92 \\
Attributes of & Liquidity in Mutual Fund & $1-5$ & 3.35 & 0.90 \\
Mutual Fund & Financial Disclosure of Mutual Fund & $1-5$ & 3.42 & 0.86 \\
& Portfolio Diversification & $1-5$ & 3.49 & 0.94 \\
& Reputation of Fund Manager & $1-5$ & 3.62 & 0.88 \\
& Compliance to Directives and Guidelines of SEBON & $1-5$ & 3.41 & 0.95 \\
& Adherence to Investment Objective & $1-5$ & 3.31 & 0.94 \\
& Availability of information & $1-5$ & 3.54 & 0.96 \\
\hline
\end{tabular}


Journal of Business and Social Sciences Research: Vol. V, No. 2 : Dec 2020

\begin{tabular}{lllll}
\hline Ease of & Initial investment Requirement & $2-5$ & 3.98 & 0.74 \\
Investment & Liquidity & $2-5$ & 4.13 & 0.74 \\
\hline \multirow{2}{*}{$\begin{array}{l}\text { Performance of } \\
\text { Mutual Fund }\end{array}$} & Return \& Capital Gain caused by the Mutual Fund & $2-5$ & 4.01 & 0.78 \\
& Investment & & & \\
& Diversification and Risk Minimization in Portfolio & $1-5$ & 3.82 & 0.94 \\
& Past Performance and Dividend History & $1-5$ & 3.78 & 0.89 \\
\hline & Adoption of Investment Strategy as per Scheme's & $2-5$ & 4.11 & 0.61 \\
& Prospectus & & & \\
Corporate & Compliance to SEBON Guidelines and Directives & $2-5$ & 4.19 & 0.67 \\
Governance and Declaration of all Material Information in a timely & $2-5$ & 4.19 & 0.66 \\
Transparency & Manner & & & \\
\hline Fund & Management by experts & $2-5$ & 4.38 & 0.67 \\
Management & Image of Fund Manager & $2-5$ & 4.14 & 0.70 \\
Qualities & Rating by external rating agency & $2-5$ & 4.07 & 0.71 \\
\hline
\end{tabular}

